Lifshitz, F., Liu, C., and Thurn, A. N. (1963). Case reportBacteroides meningitis. American fournal of Diseases of Children, 105, 487.

McVay, L. V., and Sprunt, D. H. (1952). Bacteroides infections. Annals of Internal Medicine, 36, 56

Sanders, D. Y., and Stevenson, J. (1968). Bacteroides infections in children. Fournal of Pediatrics, 72, 673.

Smith, W. E., McCall, R. E., and Blake, T. J. (1944). Bacteroides infections of the central nervous system. Annals of Internal Medicine, 20, 920.

Tynes, B. S., and Frommeyer, W. B. (1962). Bacteroides septicaemia. Annals of Internal Medicine, 56, 12.

RICHARD W. I. CoOKE*

Department of Paediatrics and Neonatal Medicine, Hammersmith Hospital, Du Cane Road, London W12 0HS.

*The Hospital for Sick Children, Great Ormond St., London WC1N 3JH.

\section{Bile acid excretion after pull-through operation for Hirschsprung's disease}

Patients who have undergone a 'pull-through' operation for Hirschsprung's disease may suffer from chronic diarrhoea and excoriation of the perianal skin which can persist for months, sometimes years (Ehrenpreis, 1971). The cause of these symptoms has not been fully elucidated and no effective form of therapy has been devised.

As part of a study of these problems the possibility that altered bile acid metabolism might play a role in altering intestinal function and producing diarrhoea was considered. We report the results of an investigation of faecal and duodenal bile acids in four such patients.

\section{Materials and methods}

Four patients who had persistent diarrhoea and perianal excoriation after a Soave pull-through operation (1964) and one patient (Case 5) with a colostomy for Hirschsprung's disease were studied (Table I).

Duodenal contents were aspirated fasting and after intravenous pancreozymin ${ }^{\star}(1$ Ivy Dog unit $/ \mathrm{kg}$ body

$\star$ Karolinska Institute, Stockholm. weight). Bile acid concentrations in the aspirates and also in three 24-hour collections of faeces were determined using $3 \alpha$-hydroxysteroid dehydrogenase and fluorimetry (Murphy, Billing, and Baron, 1970). Individual bile acids were estimated by combining this technique with thin-layer chromatography and $7 \alpha$-hydroxysteroid dehydrogenase (Haslewood, Murphy, and Richardson, 1973). Faecal fat excretion was determined on the same faecal specimens that were used for bile acid determination. Samples of fasting gastric and duodenal fluid were examined bacteriologically using the procedures of Drasar, Shiner, and McLeod (1969).

\section{Results}

The results of faecal fat and faecal and duodenal bile acid determinations are given in Table II. Faecal bile acids were raised in all 4 children who had undergone the Soave operation, when compared to values found in Case 5, and in 10 control children aged between 1 and 7 years.

It was not considered ethical to intubate normal children merely to provide control data for this study and the results of duodenal bile acid analyses in the 5 patients have been compared to 'normal values' taken from published reports. All 5 patients achieved duodenal bile acid concentrations after pancreozymin stimulation which were within the normal range (Weber and Roy, 1972), thus indicating that the bile acid losses via faecal excretion did not exceed the ability of the liver to replenish the bile salt pool.

Cases 2 and 3, who had the highest faecal bile acid levels, also had the highest values for the ratio of glycine conjugated bile acids to taurine conjugated bile acids ( $\mathrm{G} / \mathrm{T}$ ratio) in the duodenal aspirate. In this regard it must be noted that all the children studied were more than one year old and consequently would be expected to have $G / T$ ratio values within the normal adult range (Murphy and Signer, 1974).

In Case 2 an abnormally high proportion of cholic acid was found in the duodenal aspirate after pancreozymin stimulation. Further analysis indicated that conjugated deoxycholic acid (a

TABLE I

Patients studied

\begin{tabular}{|c|c|c|c|c|}
\hline Case no. & $\begin{array}{c}\text { Age at } \\
\text { operation }(m)\end{array}$ & $\begin{array}{l}\text { Age at time } \\
\text { of study } \\
(y r)(m)\end{array}$ & Diarrhoea & $\begin{array}{l}\text { Anal } \\
\text { excoriation }\end{array}$ \\
\hline $\begin{array}{l}1 \\
\mathbf{2} \\
\mathbf{3} \\
\mathbf{4} \\
\mathbf{5}\end{array}$ & $\begin{array}{c}11 \\
13 \\
13 \\
3 \cdot 4 \text { yr } \\
12\end{array}$ & $\begin{array}{rr}2 & 11 \\
3 & 7 \\
2 & 7 \\
6 & 6 \\
1 & 1\end{array}$ & $\begin{array}{c}\text { Severe } \\
\text { Severe } \\
\text { Moderate } \\
\text { Moderate } \\
\text { Absent }\end{array}$ & $\begin{array}{c}\text { Severe } \\
\text { Severe } \\
\text { Mild } \\
\text { Moderate }\end{array}$ \\
\hline
\end{tabular}


TABLE II

Bile acid concentrations and composition

\begin{tabular}{|c|c|c|c|c|c|c|}
\hline \multirow[b]{2}{*}{ Case no. } & \multirow{2}{*}{$\begin{array}{c}\text { Faecal bile } \\
\text { acids } \\
(\mu \mathrm{mol} / \mathrm{kg} \text { per } 24 \mathrm{~h})\end{array}$} & \multirow[b]{2}{*}{$\begin{array}{c}\text { Faecal fat } \\
(\mathrm{g} / 24 \mathrm{~h})\end{array}$} & \multicolumn{4}{|c|}{ Duodenal bile acids* } \\
\hline & & & $\underset{(\mathrm{mmol} / \mathrm{l})}{\text { Fasting }}$ & $\begin{array}{l}\text { Maximum } \\
\text { concentration } \\
(\mathrm{mmol} / \mathrm{l})\end{array}$ & $\begin{array}{l}\mathrm{G} / \mathrm{T} \\
\text { ratio }\end{array}$ & $\begin{array}{l}\text { TR1/D1 } \\
\text { ratio }\end{array}$ \\
\hline $\begin{array}{l}1 \\
2 \\
3 \\
4 \\
5\end{array}$ & $\begin{array}{r}25 \cdot 8 \\
38 \cdot 0 \\
34 \cdot 6 \\
31 \cdot 0 \\
8 \cdot 0\end{array}$ & $\begin{array}{l}1 \cdot 2 \\
1 \cdot 6 \\
1 \cdot 8 \\
3 \cdot 0 \\
3 \cdot 0\end{array}$ & $\begin{array}{r}45 \cdot 6 \\
1 \cdot 3 \\
12 \cdot 1 \\
15 \cdot 0 \\
11 \cdot 5\end{array}$ & $\begin{array}{l}60 \cdot 8 \\
52 \cdot 8 \\
37 \cdot 3 \\
85 \cdot 9 \\
19 \cdot 3\end{array}$ & $\begin{array}{l}2 \cdot 5 \\
7 \cdot 8 \\
6 \cdot 5 \\
1 \cdot 5 \\
1 \cdot 8\end{array}$ & $\begin{array}{l}1 \cdot 2 \\
1 \cdot 7 \\
0 \cdot 8 \\
0 \cdot 9 \\
1 \cdot 0\end{array}$ \\
\hline $\begin{array}{l}\text { Normal } \\
\text { values }\end{array}$ & $14 \cdot 3-23 \cdot 1 t$ & $<4 \cdot 5$ & $2-20 \ddagger$ & $20-68 \ddagger$ & $3 \cdot 2 \S$ & $0 \cdot 7 \S$ \\
\hline
\end{tabular}

$\star G / T$, ratio of total glycine conjugated bile acids to total taurine conjugated bile acids; TR1/D1, ratio of total trihydroxy bile acids (cholic acid) to total dihydroxy bile acids (chenodeoxycholic + deoxycholic acids).

tRange in 10 normal children.

$¥$ Values from Weber and Roy (1972).

$\S$ Values from Heaton (1972).

secondary bile acid) was absent from the bile-rich duodenal fluid of this patient and from that of Case 3. The corresponding sample from Case 4 contained a low proportion of deoxycholic acid $(5 \cdot 1 \%)$, compared to that found in Case $5(12 \cdot 1 \%)$ who had a colostomy, or to that of normal subjects (22\%, Heaton, 1972). Because of a laboratory mishap it was not possible to determine the proportion of deoxycholic acid present in the duodenal contents of Case 1.

Faecal fat levels and the bacterial flora of the upper small intestine were both normal.

\section{Discussion}

All 4 patients with chronic diarrhoea and perianal excoriation after their pull-through operation for Hirschsprung's disease had increased faecal bile acid excretion when compared to normal subjects. In 3 patients the increased bile acid excretion was associated with a reduced proportion of the secondary bile acid, deoxycholic acid, in the bile-rich duodenal fluid.

In the normal subject some $85 \%$ of the total amount of bile acids discharged into the duodenum is absorbed across the terminal ileum; as much as $15 \%$ may be absorbed by the colon (Samuel et al., 1968). The faecal bile acid excretion found in the 4 patients with chronic diarrhoea in the present study could be consistent with colonic rather than ileal malabsorption. The following observations support the concept of colonic malabsorption. The degree of faecal bile acid loss was small when compared to that of patients with ileal resection, whose bile acid excretion may be close to the maximal hepatic synthetic rate (Heaton, 1972).
The G/T ratio, though raised in 2 patients, did not reach the values of 10 to 20 usually found in patients with ileal dysfunction (Heaton, 1972).

Colonic malabsorption of bile acids per se is unlikely to be the direct cause of the troublesome diarrhoea or of the perianal excoriation in the patients studied. Diarrhoea in patients with ileal resection which is induced by excess bile acid loss into the colon is not commonly associated with perianal skin excoriation. It is probable that the level of faecal bile acids shown in the present study indicated colonic dysfunction which, since such losses were not evident in the patient with a colostomy for Hirschsprung's disease, must be considered to be a consequence of, or associated with, the pull-through procedure.

\section{Summary}

Four children with chronic diarrhoea and perianal excoriation after a pull-through operation for Hirschsprung's disease have been shown to have increased but not markedly raised levels of faecal bile acids. Bile acid analysis of the 'bile-rich' duodenal fluid obtained after pancreozymin stimulation in 3 of the patients indicated a marked reduction in the proportion of deoxycholic acid conjugates. These findings are compatible with colonic malabsorption of secondary bile acids in these patients which is related in some way to the pull-through operation, but which is not likely to be the cause of the diarrhoea and the anal excoriation.

Financial support was received from the Endowment Fund of the United Birmingham Hospitals. H.G. was supported by a grant from the Swiss National Science Foundation. 


\section{REFERENCES}

Drasar, B. S., Shiner, M., and McLeod, G. M. (1969). Studies on the intestinal flora. 1: The bacterial flora of the gastrointestinal tract in healthy and achlorhydric persons. Gastroenterology, $56,71$.

Ehrenpreis, T. (1971). Hirschsprung's disease. American fournal of Digestive Diseases, 16, 1032.

Haslewood, G. A. D., Murphy, G. M., and Richardson, J. M. (1973). The direct enzymic assay of $7 \alpha$-hydroxy bile acids and their conjugates. Clinical Science, 44, 95.

Heaton, K. W. (1972). Bile Salts in Health and Disease. Churchill Livingstone, Edinburgh and London.

Murphy, G. M., Billing, B. H., and Baron, D. N. (1970). A fluorimetric and enzymatic method for the estimation of serum total bile acids. Fournal of Clinical Pathology, 23, 594.

Murphy, G. M., and Signer, E. (1974). Bile acid metabolism in infants and children. Progress report. Gut, 15, 151.

Samuel, P., Saypol, G. M., Meilman, E., Mosbach, E. H., and Chafizadeh, M. (1968). Absorption of bile acids from the large bowel in man. Fournal of Clinical Investigation, 47, 2070.

Soave, F. (1964). Hirschsprung's disease : á new surgical technique. Archives of Disease in Childhood, 39, 116.

Weber, A., and Roy, C. C. (1972). The malabsorption associated with chronic liver disease in children. Pediatrics, 50, 73.

H. Gaze, * G. M. Murphy, $†$ R. Nelson, J. J. CorkerY, and Charlotte M. ANDERSON $\ddagger$

Institute of Child Health, University of Birmingham, Francis Road; and Children's Hospital, Birmingham.

Present addresses: *Universitäts Kinderklinik, Bern, Switzerland. †Gastroenterology Unit, Guy's Hospital, London SE1.

¥Correspondence to Prof. C. M. Anderson, Institute of Child Health, Francis Rd., Birmingham B16 8ET.

\section{Serum cortisol concentrations in children with chronic renal insufficiency}

Raised plasma corticosteroids may retard growth whether their source is exogenous or endogenous, as in the case of Cushing's syndrome. Fanconi (1954) postulated that adrenal hypertrophy and excess circulating corticosteroids, occurring in response to stress, might limit the growth of children with chronic renal disease. Further investigations have shown that rats rendered uraemic by either subtotal nephrectomy or induced nephritis develop adrenal hypertrophy (Deane and Masson, 1951; Morrison, 1962) and there have been reports of an abnormal diurnal rhythm and of raised midnight and morning plasma cortisol concentrations in adults with severe renal failure (Varghese et al., 1969; Snodgrass et al., 1970). However, in the above reports the cortisol concentrations were determined using a fluorimetric technique similar to that described by Mattingly (1962). By this method only $59 \%$ of the total fluorescence may in fact be due to the free 11-hydroxycorticosteroids, cortisol, and corticosterone (James, Townsend, and Fraser, 1967) and mistakenly raised values would be obtained in the presence of an excess of noncortisol fluorimetric material. Cortisol may now be estimated by the use of competitive protein binding (Murphy, 1967); this is a more specific determination and eliminates these possible errors.

Plasma cortisol concentrations show a diurnal rhythm, the lowest levels being found soon after midnight, thereafter rising to a morning peak. Any abnormality of secretion resulting in excessive values should therefore be demonstrable during the night. The nocturnal concentrations of serum cortisol have been determined by both fluorimetric and competitive protein binding techniques as part of a more comprehensive study of the growth retardation of children with chronic renal insufficiency.

\section{Patients and methods}

A method for the continuous sampling of venous blood through the night, in hourly aliquots, has been described elsewhere (Howse et al., 1974). Serum cortisol concentrations were determined both flourimetrically, by a modification of the Mattingly technique (1962) and by competitive protein binding, utilizing a modification of the technique described by Murphy (1967). Control values were obtained for the competitive protein binding technique in 5 boys with short stature who had a normal plasma cortisol response to hypoglycaemia after an insulin sensitivity test. Their mean age was 11 years (range 7 to 14 years). The hourly aliquots for serum cortisol concentration in these children were only available up to $4.00 \mathrm{a} . \mathrm{m}$. 11 children with varying degrees of renal insufficiency were investigated and the details are shown in the Table. There were 8 boys and 3 girls; their mean age was 11 years (range 4 to 16 years). No patient was on any drug known to fluoresce or interfere with the estimation of cortisol by the competitive protein binding method.

\section{Results}

The means $\pm 1 \mathrm{SD}$, for the hourly nocturnal serum cortisol concentrations determined fluorimetrically and by competitive protein binding in children with chronic renal insufficiency are shown in the Fig. The cortisol concentration in all these samples when determined fluorimetrically was higher than that obtained by competitive protein binding and the mean hourly values differed between the two methods by approximately 18 $\mu \mathrm{g} / 100 \mathrm{ml}$. The values obtained by competitive protein binding for the serum cortisol concentration in the renal patients were no different from those in the controls (Fig.). The renal patients showed a normal diurnal rhythm and their midnight and morning values were similar to other published normal data for plasma samples (Barnes et al., 1972.)

Four of the children with chronic renal insufficiency had short stature (Table). There was no significant increase in the serum cortisol concentra- 